\title{
SOME TAX IMPLICATIONS OF BRITISH ENTRY INTO THE COMMON MARKET
}

\author{
NORMAN I. MILLER*
}

\section{INTRODUCTION}

In examining the implications of Britain's joining the Common Market, one is immediately struck by the fact that, even if no other changes were required in the United Kingdom, the alterations in the tax structure resulting from the impending entry would in themselves be sufficient to affect almost every aspect of Britain's industrial, commercial, and social life. To investigate the full impact of British entry in terms of taxation is, therefore, virtually impossible. However, the recent statement of the Chancellor of the Exchequer has given concrete expression to a number of the more immediate and important of the tax implications for Britain, at least as conceived by the present government, and these would appear to provide a logical and convenient point from which to begin such an examination. ${ }^{1}$ Three of the items mentioned in the Chancellor's speech have particular and obvious relevance to Britain's joining the Common Market, and it is these three items which will be investigated in detail in this paper. They are the introduction of the value added $\operatorname{tax}$ (VAT), the reform of the corporation tax, and the creation of new policies to stimulate industrial development in certain areas of Great Britain.

\section{I}

\section{The Value Aded Tax}

\section{A. The Proposed British VAT}

The European Communities Bill now before the U.K. Parliament makes it clear that, if it is enacted, Britain will be committed to adopting as law all of the obligations and liabilities existing under certain EEC treaties ${ }^{2}$ in effect as of January $22,1972^{3}$ and all of those which may come into being in the future as part of such treaties, provided such obligations as may be created will have legal effect without the need for further legislation. ${ }^{4}$ Thus, insofar as a value tax is concerned, the United Kingdom, on enactment of the European Communities Bill, will be bound to introduce such a levy in accordance with the blue print established by the

\footnotetext{
- Partner, Baker \& McKenzie, Chicago, Illinois and London, England.

${ }^{1}$ See statement of the Chancellor of the Exchequer, the Rt. Hon. Anthony Barber, M.P., in the House of Commons, March 21, 1972, reported in 833 PARL. DEB., H.C. (5th ser.) 1343-90 (1972).

${ }^{3}$ These treaties are the pre-accession treaties listed in part I of schedule I of the European Communities Bill (Bill 68) 1972 and include the Treaty Establishing the European Economic Community, March 25, I957, 298 U.N.T.S. 14-94 [hereinafter referred to as the Rome Treaty.]

${ }^{3}$ This is the date on which the United Kingdom signed the Treaty of Accession to the European Economic Community and the European Atomic Energy Community, Jan. 22, 1972, CMND. No. 4862.

-European Communities Bill (Bill 68) 1972, pt. I, \$2(I).
} 
Council for the European Economic Community. The fact that the present Conservative Government has already committed itself to introducing a value added tax is, therefore, no more than a recognition of the inevitable. ${ }^{6}$

The structure of the value added tax, as laid down by the Chancellor in' his White Paper of March, I972, has obviously benefited from the intensive investigations undertaken by the British Revenue authorities into the workings of this tax in those other European countries, particularly Denmark, which have already adopted it. $^{7}$ These preliminary studies revealed that the problems of administering the tax increase in direct proportion to the number of different rates which are imposed on different transactions. In order therefore to reduce these complications, the British Government has settled, at least initially, for a single rate tax with a dual system of exemptions.

The rate proposed by the British Government is ten per cent on the supply of goods and services. However, provision has been made to adjust the rate either way by 2.5 per cent if the economics so require, ${ }^{8}$ though any Treasury Order increasing or decreasing the tax will only be effective for a period of one year unless renewed. ${ }^{0}$

The British Government has, of course, followed the directions of the Council of the European Economic Community ${ }^{10}$ in creating the tax so that the framework of the VAT in Britain will be essentially the same as that presently in force in the Common Market. ${ }^{11}$ As its name implies, each trader will pay a tax on the value which he adds to any goods or services during his particular stage of the production

\footnotetext{
This blueprint was established by a series of directives issued by the Council of the EEC of which three are most important. See First Council Directive: Harmonization of Member State Laws on Turnover Taxes, issued Apr. $x x, 1967$, in $\mathrm{r}$ CCH Comm. Mkt. Rep. I $311 \mathrm{r}-17$, Journal officiel des ComMUNaUtís EURopḱennes, Apr. I4, 1967, at r30x [hereinafter cited as E.E.C. J.O.]; Second Council Directive: Harmonization of the Member State Turnover Tax Laws-Structure and Procedure for Applying the Common Added-Value Tax System, issued Apr. II, I967, in I CCH CoMM. MkT. Rep. T3135-57, E.E.C. J.O., Apr. I4, 1967 , at 1303; Third Council Directive: Harmonization of the Member States' Laws on Turnover Taxes: Introduction of the Tax on Value Added in the Member States, issued Dec. 9, 1969, in I CCH CoMn. MKr. REp. I $3161-65$, E.E.C. J.O., Dec. 20, 1969, at 34 .

The Conservative Government had, in fact, committed itself in $197 x$ to a major reform of the tax system, which included the abolition of the Selective Employment Tax and a reconstruction and replacement of the existing system of indirect taxation-involving purchase tax and tax on such items as hydrocarbon oils and tobacco-by a broad based value-added tax. Thus, although the proposed VAT legislation is obviously a reflection of Britain's intent to join the Common Market, it seems reasonably clear that the present government in the United Kingdom would have introduced it regardlcss of Britain's entry. See the U.K. Government Green Paper on the Value-Added Tax, published by order of the Chancellor of the Exchequer as VALUE-ADDED TAX, CMND. No. 462x, at 3 (1971).

${ }^{7}$ See U.K. Government White Paper containing the draft legislation for the VAT, published by order of the Chancellor of the Exchequer as VALUE-ADDED TAX, CMND. No. 4929 (1972) [hercinafter cited as VAT DRAFr]. This draft has now been incorporated in the Finance Bill (Bill IIX) 1972. Although all references are to the VAT Draft, they are equally applicable to the Finance Bill because the same section numbers and schedules have been retained in the Bill.

${ }^{s}$ However, it is questionable whether Britain will be able to maintain a single rate cven at the increased level of $12 \frac{1}{2} \%$, see text accompanying notes $28 \& 29$ infra.

- VAT DRaft cl. 9(3).

${ }^{10}$ Note 5 supra.

${ }^{11}$ With the exception of Italy, which has recently been given until January I, 1973, to bring a VAT into operation.
} 
or distribution process. The tax will be collected from each of the traders as the goods or services are passed on. Because of the credit system, however, the tax will eventually fall entirely on the final purchaser. Just as the value of any goods or services represents, at the point of supply to the final consumer, the sum of all the individual values added by the various traders involved in making the goods available, so the final tax when paid by the consumer will represent the sum of all the taxes paid by successive traders during the course of production. As each trader will pay only the VAT attributable to his contribution to the final value of the goods or services, it does not matter how many stages there are in the process of creating the final product: for any given final value, the final tax will be the same. It is this last factor which constitutes the major difference between the VAT and the "cascade" form of turnover tax which was in effect in Germany prior to Ig68. Under the latter system, the assessment was based on the gross value of the goods or services including the tax itself. Thus the tax was passed on to all customers in a cumulative amount, and the more stages involved in production of the final article, the larger the tax.

In his accounting and actual payment of the tax, the VAT trader will reconcile his liability on an overall basis, rather than as a per transaction entry. Whenever he buys a product or service to which the standard rate of value added tax applies, the trader will pay his supplier tax at the appropriate rate of ten per cent, and when he in turn supplies goods or services to his own customers, he will charge them tax at the same rate. At regular intervals he will make a return to the Customs and Excise authorities in which he will furst add up all the tax he has paid to his trade suppliers in a particular period ${ }^{12}$ (known as the "input tax") ${ }^{13}$ and then total all the tax he has charged to his own customers on sales in the same period (the "output tax").14 The difference between these two totals will then be paid over to the Customs and Excise. If the input tax is greater than the output tax because the trader is, for example, building up his inventories or making a major purchase of capital equipment, he will be entitled to a refund of tax from the authorities.

Although apparently straightforward, this method of accounting may raise cash problems for the trader. As the legislation is now drawn, the tax will be payable on each taxable transaction performed in a given accounting period and not on the receipts of payment for the transactions in that period. ${ }^{15}$ In service industries

\footnotetext{
${ }^{12}$ The standard accounting period will be three months, with a month's grace for paying the quarter's net tax. VAT DRAFT at 3 , para. i6.

${ }^{13}$ VAT DRAFT cl. 3 .

14 Id.

${ }^{16}$ Although the VAT Draft does not state this expressly, it may be implied from a number of its provisions, see, e.g., VAT Drafr cl. 30; id. schedule 3, $\$ 4$. The Green Paper on the VAT, supra note 6, makes it abundantly clear that liability arises on performance of a taxable transaction and not on receipt of payment for it, id. paras. 2.5 \& 3.I2. Indeed, as the legislation is now drawn, the tax pointthat is, the time at which the VAT is exigible-may occur even before the tax invoice is issued. See VAT DRAFT cl. 7(2). The importance of the invoice lies in the fact that its receipt is a prerequisite to the taxpayer's claiming any credit for the input tax. See The Nuts and Bolts of VAT, TrE Economist, Apr. 8, 1972 at 63. See also A. TaIt, VaIUe AdDed Tax 40, I29-r4o (I972); D. Parkinson, V.A.T. A Practical Introduction to Systemss for Value Added Tax 29 (1972).
} 
especially, where the output value may be high and the input comparatively low, the difficulties could be particularly acute. ${ }^{16}$ Another problem which could arise under the system is that of bad debts. At the present time the legislation is silent on this particular issue, though it is known to have been considered by the draftsmen. The matter is one which could conceivably be dealt with in the future by regulation because section $30(4)$ of the draft law gives the Commissioners of Customs and Excise the power to make provision by regulation for the adjustment of accounts in cases where tax has been charged by reference to a consideration and the amount of the consideration is reduced or no consideration becomes payable. However, such indications as exist suggest that the Government is of the view that it should not be required to forfeit its own revenue because of the taxpayer's failure to assess the credit worthiness of its own customer and that, therefore, no adjustment in the VAT payable is warranted in respect of bad debts. ${ }^{17}$ On the ancillary problem of trade discounts, however, the draft provides that a tax will be levied on the discounted value, that is, on the face amount of the invoice, less the discount. ${ }^{18}$

As previously stated, the structure of the British VAT envisages a dual system of reliefs from the tax, either by way of a straightforward elimination of liability to account for tax on performance of the transaction or, alternatively, by way of the so-called "zero rating." The difference between the two lies in the fact that a total exemption interrupts the operation of the credit mechanism which is inherent to the application of the VAT to the process of production and sale. While an exempt trader is free not to charge any tax to the person to whom he is supplying the goods or services, he is also precluded from taking credit for or reclaiming any input tax which he has paid in respect of the exempt goods or services. Unless he engages in other nonexempt transactions, the trader will lose the credit and will either have to bear the cost of the input tax himself or, as is more likely, recoup it through the prices he charges his own customers. ${ }^{19}$ A dealer in zero-rated goods and services is also free not to charge the VAT to his customers, but unlike the trader in the totally exempt transaction, he is free to take credit for or reclaim any input tax already paid to his own suppliers. A zero-rated transaction is really one which is technically within the tax, but, as its name implies, is subject to assessment at a zero rate. It is this latter mechanism which saves exports from the full impact of the VAT. The trader exporting goods and services is held to be engaged in a zero-rated transaction and it

\footnotetext{
${ }^{16}$ Advertising agencies may not be affected too much as newspaper advertisements will be cxempt by zero rating. VAT DrafT schedule 4, group 4. Lawyers, on the other hand, could be badly affected, since their services are not eligible for any exemption. With respect to advertising, however, it is interesting to note that in the Second Council Directive of April II, 1967, supra note 5, which sets out in detail the structure of the VAT to be adopted in the EEC, annex B specifically lists commercial advertising services as being compulsorily subject to tax. Id. art. 6(2); annex A, para. ro; annex B, itcm 4 .

${ }^{17}$ Cf. Joseph, V.A.T.-Points to Watch, Law Goardian, March, 1972, at 7. The various accountancy bodies in the United Kingdom have made submissions to the Government arguing against this position. See r66 THE AccountanT 549 (I972).

18 VAT DRAFT schedule $3, \$ 4$.

${ }^{19}$ If he chooses to recoup it, he cannot show such import tax as a separate element in his own sales invoice. See VALUE-ADDED TAX, supra note 6, §2.13; VAT DRAFT $\S 30(2)$.
} 
is this which enables him to reduce his selling price to the foreign customer by an amount at least equal to the VAT.

The draft legislation also proposes exempting small traders from the tax and from registration as a taxpayer. A small trader in this context is one whose turnover in taxable supplies of goods or services does not exceed $£ 5,000$ a year. ${ }^{20}$ Traders who fall within this class will not be required to keep VAT records or to account to the Customs and Excise. ${ }^{21}$ Persons, including companies and partnerships, whose turnover in taxable supplies of goods or services, including zero-rated supplies, exceeds or is likely to exceed $£_{5}, 000$ will be required to register with the Customs and Excise and to account for tax on their transactions. ${ }^{22}$

Two other points are worth noting as regards Britain's impending value added tax. First, no exception or special provision is made for the acquisition or disposal of capital goods. The problem was apparently considered with some care, but it was felt that any advantages which special treatment might secure would be unlikely to justify the additional administrative complications which would be created. ${ }^{23}$ Thus, when a capital asset is acquired by the trader, the input tax paid on it will be treated in the same way as any other input tax: it will create an immediate credit for the accounting period in which the tax invoice is received and will be eligible to offset an appropriate amount of output tax or be subject to refund by the Customs and Excise authorities. Similarly, when capital goods are disposed of, they will be treated like any other second-hand goods sold in the course of business: the value of the goods will be included in the total value of the trader's taxable sales for the period in question and the trader will be accountable to the Customs and Excise for the appropriate output tax. The second point of interest in the British VAT is the application of the tax to imports. According to the draft law, the payment of VAT in respect of imported goods will be treated in the same way as customs duty, except that the Commissioners of Customs and Excise will have power to make regulations allowing taxable persons to take delivery of imported goods and defer the payment of the tax chargeable. ${ }^{24}$ Wholly taxable persons will be allowed to account for import value added tax by entering it in their ordinary output tax account and, at the same time, claiming an input tax deduction on the same amount. The effect of this will be to cancel out the two items in the return for the accounting period in question. However, when the imported goods are subsequently sold or disposed of, output tax will be chargeable and accounted for in the normal fashion. In this way the importer will be put on the same footing as regards the time of payment of the tax as the domestic trader dealing in the same type of goods.

\footnotetext{
${ }^{20}$ VAT DRAFT schedule I, $\$ \mathrm{I}$.

${ }^{21}$ Small traders may, however, be allowed to register voluntarily if it is to their advantage. $I d$. schedule I, $\$$ II(b).

${ }^{22} I d$. schedule I, $\$ \mathrm{I}(\mathrm{b})$.

${ }^{23}$ Id. $5, \$ 22$.

"Id. cl. I8.
} 


\section{B. Harmonization of VAT's Within the EEC}

One of the complicating features regarding the international aspects of the value added tax is, of course, that different criteria may be and, indeed, are applied in the different member states of the Community in determining liability. The situation becomes particularly confused in respect of the taxation of services. Under French VAT law, for example, the rendering of services will be an assessable transaction if such services are, in fact, rendered within France or if the right transferred is exploited within France or, in the case of leasing of equipment, if the equipment is used in France. ${ }^{25}$ Thus, if a foreign engineering concern were to draw up plans for a factory to be built in France, this service would be subject to the French value added tax, notwithstanding the fact that all the plans and the work associated with their preparation were done outside of France. ${ }^{2 B}$ Under the proposed British system, however, the principle of territorial utilization of services does not appear to be controlling. Clause eight of the VAT draft states that liability will only arise if services are supplied in the United Kingdom. ${ }^{27}$ Moreover, unlike the French system, if the services are such as might be considered as supplied either in or outside the United Kingdom, they will only be taxable if the person rendering them carries on business in the United Kingdom through a branch or agency. ${ }^{28}$

The existence of these different principles regarding the international aspects of the VAT can, of course, result in double taxation. If the foreign engineering concern in the example previously cited were a British firm of consultants and all the work in planning the French factory were performed in the English office of this firm, the work would, prima facie, be subject to English VAT, notwithstanding that the services themselves would be utilized in France and thereby also subject to the French value added tax. ${ }^{29}$

\footnotetext{
${ }^{25}$ C. GÉnERAI des IMpôts art. 258 (Petits Codes Dalloz 1966-67). Formerly, the rendering of services was subject to the taxe stur les prestations de services. This tax was abolished, however, by the Statute No. 66-ro of Jan. 6, r966, art. I, [1966] E.E.C. J.O. Jan. 7, at I63, [rg66] D.S.L. 67. The law of January 6 , 1966 , will eventually be formally incorporated in the C. Général des Impôts. Howcver, by virtue of Decree No. 67-II64 of Dec. 15, I967, [1967] E.E.C. J.O. Dec. 28, at 12, 793, [1968] D.S.L. 35 and Decree No. 68-372 of Apr. 24, xg68, [I968] E.E.C. J.O. Apr. 26, at 4258, [1968] D.S.L. I69, it is possible to cite the articles of the C. Général des Impôts as though such modification had alrcady been effected.

${ }^{20}$ Taxes sur le chiffre d'affaires. Application de la loi No. 66-ro du 6 Janvier r966 portant réforme des taxes sur le chiffre d'affaires. Instruction Générale du 20 Novembre rg67. Instruction Section I2r.2I (French Tax Administration's commentary on the new French Turnover Tax legislation).

${ }^{27}$ VAT DRAFT Cl. 8(I), $2(4)$.

${ }^{28} \mathrm{Id}$. cl. 8(4). Under French law, on the other hand, the person supplying the services has the burden of showing what portion of his services is rendered outside of France and the proportionate value of such services. If he fails to discharge the burden, the full value of all the services are taxable. C. GÉf́rat des Imipôts, annex I, art. 26 quater. (Petits Codes Dalloz r966-67.) For a general discussion of problems arising from the French approach to the taxation of international services, see Goldsmith, About Problems Relating to the French TVA on International Services, Commerce IN France, Nov., I969, at I4 (published by United States Chamber of Commerce in France).

${ }^{29}$ The same result could also follow as between Germany and France if the concern were a German firm. Cf. Umsatzsteuergesetz (Mehrwertsteuer), of May 29, 1967, $\$ 3$ (10) \& 3(II), [1967] BGBL 546. The U.K. Treasury has been given power under the VAT Draft legislation to amend clause $8(4)$ either generally or to deal with specific situations, and it is possible that it might be persuaded to exercise this
} 
The proposed legislation makes no specific reference to patents and know-how, so that the question of tax liability in respect of royalties and fees paid to a U.S. licensor, for example, would have to be determined in accordance with the general principles discussed above. Thus, if secret information were supplied to a British user entirely from abroad, there should be no tax assessable on the fees paid to the foreign licensor because no services would have been supplied in the United Kingdom. The question of liability as regards royalties paid overseas by a British taxpayer for the use of a U.K. patent or registered trademark is, however, not so clear. Although the granting of the whole or any part of a right for consideration is a supply of services, ${ }^{30}$ it only becomes a taxable supply of services if such services are supplied in the United Kingdom in the course of a business carried on by the supplier. ${ }^{31}$ The draft legislation is silent as to what constitutes the carrying on of a business, though there is a well developed body of income tax case law on this subject. However, in this particular instance, it is virtually impossible to conceive of the phrase being interpreted other than in a manner which would make such royalties liable. ${ }^{32}$

Despite the fact that the United Kingdom is committed to the adoption of a value added tax by 1973 , it is by no means impossible that Britain, like Italy and Belgium, will request a later deadline so as to permit an orderly transition. While a great deal of work has been done by the Customs and Excise authorities to prepare for the advent of the tax, comparatively little instruction has been given to the taxpayers who must actually cope with the tax and accompanying regulations. The continual reassurances issued by the Government as to the ease of administration and application of the tax must be viewed somewhat skeptically. It is middle management which will have to assume the day-to-day burden of dealing with this levy, and it is precisely this middle management which is lacking in experience and information as to how the tax will apply.

Apart from the administrative difficulties, there are, of course, the substantive problems which will arise and which to some extent are already apparent. Future Treasury regulations may well be able to deal with most of these, though some of them will undoubtedly require consultation with the European Commission itself. Even at this stage, with the U.K. legislation only in draft form, it is possible to see that drastic changes in the structure now contemplated may be required in order to satisfy the tax harmonization measures prescribed by the EEC. The European Commission has already indicated that it will present proposals for harmonization

power in order to prevent the services being subject to double taxation. VAT DRAFT cl. 8(6): Although the services in this example would be zero rated because of their use abroad, this in itself would only serve to substitute the French rate of tax for the English rate.

${ }^{30}$ Id. cl. $5(8)$.

${ }^{31}$ Id. cl. $2(4)$. Such business need not apparently be carried on in the U.K.

${ }^{32}$ Cf. EEC Second Council Directive of Apr. II, I967, supra note 5, annex B(I). France has made special arrangements with a number of countries, including the United States and the United Kingdom, to exempt royalties from the VAT if paid under patent license agreements to the actual inventor. 
of the taxable base of the VAT to the European Council before January $1,1973 .{ }^{33}$ By the middle of 1973 , the Commission also hopes to present its proposals for the first steps in harmonization of the actual tax rates. This will involve a reduction in the number of national tax rates, the establishment of a common list of goods and services subject to reduced rates of tax, and a partial harmonization of both the normal and reduced rates. ${ }^{34}$ Complete harmonization of all tax rates will not take place, however, until the last stage of the economic and mon'etary union of the Community. ${ }^{35}$

\section{Corporation Tax Reform}

\section{A. Britain's Choice of an Imputation System}

One of the interesting features of the Rome Treaty is that, although specifically mentioning the harmonization of indirect taxes, ${ }^{36}$ it makes no corresponding reference to direct taxation. The authority for action in this particular area is derived from the general powers given to the Council under Article 100.37 It may very well be that this omission was not unintentional: the problems involved in harmonizing direct taxation of individuals and of corporations are, of course, immense. As the Neumark Report pointed out, ${ }^{38}$ the system of direct taxation in force in each member state is an expression of the individual country's economic structure, tax morality, political ideology, and social, public health, and welfare

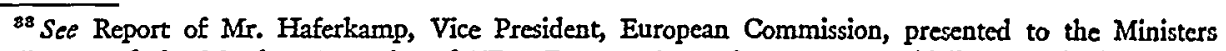
of Finance of the Member Countries of EEC, Europe, Apr. 28, r97x, at 3 (daily news bull., Agence Internationale d'Information pour le Presse, Luxembourg).

${ }^{34}$ See II European Taxation II/63 (I97I). It is interesting to note that in one of the Community studies published in Brussels in $x 970$, the harmonization of the VAT was discussed in the context of a $15 \%$ rate, with a reduced rate of $7 \frac{1}{2} \%$ on such essentials, as food, fuel, etc. See Commassion DEs

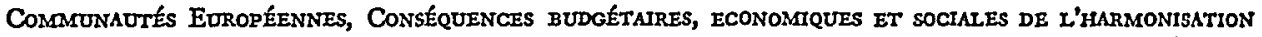
des taUX de IA TVA daNs La C.E.E., Concurrence: RApprochement des Legislations No. I6 (1970). Such harmonization of rates is, of course, a prerequisite to implementing the Community budget arrangements. Britain, like all the other member states, has undertaken from January I, 1975, to contribute to the Community budget, if so required, an amount up to the total receipts obtained from a VAT imposed at a rate of $x$ \%. See White Paper, The United Kingdom and the European Comanunities, CMnd, No. 4715, at paras. 91-96, annex A, paras. 3-4 (I97r); 166 ThE ACcountaNT 401 (1972).

${ }_{35}$ The last stage of the economic and monetary union is expected to be completed by the end of this decade. See Darendorf, The European Community in the World, in Current Legal Aspects of Doinc Business in Europe 3 (197I). (Proceedings of an ABA National Institute, March 26 \& 27, 197r, Chicago. Sponsored by the Section of International and Comparative Law.) The first phase in this direction was commenced on February 8 and 9, I971, when the members of the Community agreed, inter alia, to co-ordinate foreign exchange operations and exchange rates. Compromise Plan for Economic and Monetary Union, 2 CCH COMN. MRT. Rep. I 9415 (I97I).

${ }^{80}$ Rome Treaty, art. 99.

${ }^{87}$ This expressly gives the Council authority to issue directions by unanimous vote approving proposals of the Commission for the approximation of legislation in the member countries which have a direct impact on the establishment or functioning of the EEC.

${ }^{2}$ European Economic Communtry Commision, The EEC Reports on Tax Harnonization (1963) (unofficial translation by the Int. Bureau of Fiscal Documentation) [hereinafter cited as NeuMarx RzPORT]. Also found at I CCH COMM. MKT. REP. I $3201-85$.
} 
policies. ${ }^{30}$ These differences cannot easily be ignored, reflecting as they do the material and cultural peculiarities of the members, and thus, irrespective of how desirable the harmonization of direct taxation' may be, ${ }^{40}$ it is unlikely that a comprehensive system will emerge in the near future. ${ }^{41}$

Despite the difficulties involved in developing a coherent policy as regards the approximation of the Community tax laws, certain trends in the field of corporate taxation are becoming discernable in the member states, though it is impossible to state with any conviction that these trends represent a considered overall approach to the problem. However, these developments obviously have implications for the United Kingdom and some of these have already manifested themselves.

In 197 I the U.K. Government announced its intention of reforming the structure of corporation tax in Great Britain so as to eliminate the economic double taxation of company profits distributed to investing shareholders which occurs under the so-called "classic system" presently obtaining both in the United Kingdom and the United States. ${ }^{42}$ The two systems of taxation examined by the Government as possible alternatives were the two rate arrangement now in force in West Germany and the imputation system used in France. The two rate structure aims to reduce the aggregate tax burden on corporate profits by imposing corporation tax at a lower rate on dividends than on those profits retained in the company. Such dividends are then taxed as ordinary income when they reach the hands of the shareholders. Under the imputation system, on the other hand, corporate tax is imposed at the same rate on retained and distributed income. In order to reduce the economic double taxationi on those company profits distributed to shareholders, part of the corporation tax attributable to those profits is credited against the personal tax liability of the shareholder receiving the distribution.

Of these two alternatives, the British Government originally favored the two rate system subject to suitable safeguards. ${ }^{43}$ The Government was not in favor, however, of returning to the arrangements in effect in the United Kingdom prior to I965, which more or less achieved the desired result, since this could, in its view, lead to a serious distortion of investment in the United Kingdom. ${ }^{44}$ To assist the

\footnotetext{
${ }^{80}$ Id. at I02. For examples of how these differences manifest themselves in the methods of collecting revenue in the member states, see D. Dosser \& S. HaN, TAXes in the EEC aNd Britain: The Problem of Harmontzation (Ig68), especially ch. 2.

${ }^{10}$ The Neumark Report recognizes the impossibility of developing an ideal system for all of the EEC. As it points out, the goal of the Community should be to eliminate most disparities which curb or distort competition in an integrated market. NEUMARK REPORT 102.

${ }^{2}$ Some experts put it at some 10-15 years ahead. See the evidence of Professor D.G.M. Dosser in Select Committee on Corporation TAx, Report, H.C. Rep. No. 622, Sess. I970-71, at I27, para. 481 (1971).

${ }^{23}$ See the U.K. Government Green Paper, published by order of the Chancellor of the Exchequer as Reform of Corporation Tax, Cmnd. No. 4630 (I975).

${ }^{48}$ Notably in respect to U.K. subsidiaries of foreign companies.

"See REFORM OF CoRporation TAx, supra note 42, at 3. The Government's objections to the pre-Ig65 system's distortion of U.K. investment is, of course, equally applicable to the Government's proposed imputation system with its minimum corporation tax charge.
} 
Government in determining which system should be adopted, a Select Committee of the House of Commons was formed to consider this particular aspect of the proposed tax reform. The Committee heard evidence from various bodies and interested parties and, after due deliberation, concluded that the imputation system was the better one for the United Kingdom. As the Committee saw it:

The arguments in favor of the imputation system spring basically from this country's position as an international trader and investor. All whom Your Committee questioned agreed that the imputation system was preferable to the two rate system as a basis for the re-negotiation of double taxation agreements (which will be necessary whatever system is finally adopted) ....

Your Committee think it likely that harmonization within the EEC would in the first place be facilitated by the adoption of imputation here. ${ }^{45}$

Both the Select Committee and the Government, in' finally adopting the former's recommendations, have acknowledged that they were influenced by the developments in the EEC an'd the trend towards harmonization of corporate taxation which was and is manifesting itself there. ${ }^{48}$ However, as has already been stated, it is difficult to accept that these so called "trends" reflect any overall pattern. A brief chronological outline will serve to show how haphazard these developments have in fact been.

In 1953 West Germany changed from a classic system of corporate taxation, similar to that now in operation in the United States and in the United Kingdom, to the two rate system. In Ig60 the Dutch Government proposed to its Parliament that it switch from the classic system then in effect to the German tax system. In I963 the Neumark Report also recommended the adoption of the German two rate system by the member countries of the Common Market, and in that same year Belgium moved from its schedular system of taxation, which imposed tax on different categories of income, to a system which combined individual tax assessment with a corporation tax liability. The structure which finally emerged in Belgium as regards taxation of corporate profits was a credit arrangement with an element of the German two rate system.

I965 saw the United Kingdom, after many years, abolish its credit system in favor of the classic system. France, in the meantime, switched from the classic system to the imputation or credit system. In the same year, no doubt as a result of the changes in Britain and France, the Dutch Government withdrew its proposal of I 660 and announced its intention to introduce the French imputation system.

In Ig67 the German Finance Ministry recommended a move from the two rate system to the French imputation system. One year later the Dutch Government abandoned its proposal to adopt the imputation system and stated that it would retain, for the time being, the classic system of taxation. Italy, having finally decided

\footnotetext{
${ }^{45}$ Select Comm. on Corporation Tax, Report, H.C. Rep. No. 622, Sess. 1970-7x, at xiii-xiv.

${ }^{16}$ Id. See also Statement of the Chancellor of Exchequer, supra note I.
} 
in 1968 that it should do something to reform its corporate tax laws, moved from its then existing schedular structure to the classic system. Throughout this entire period Luxembourg maintained a discreet silence: it studied the various systems and decided that, pending developments in the Common Market, it would keep its existing classic system. ${ }^{47}$

Possessed with the insight peculiar to governments, the United Kingdom has apparently managed to detect a trend in these various developments. Presumably it is in keeping with this trend that it has now decided to replace its own classic structure with the imputation system.

This chronology of tax "happenings" would not be complete, however, without mentioning at least two other events. The first concerns the recent furor in France over the fact that, by virtue of the imputation system, the French Prime Minister had avoided paying any income tax at all for some period of time. While the actions of M. Chaban-Delmas were apparently quite legal, the publicity given to the tax advantage derived by a comparatively few people holding shares and able to utilize the credit under the imputation system may well make the latter politically unacceptable in the future, whatever may be its inherent economic attractions. Indeed, there is now a bill before the French National Assembly to abolish the system entirely and replace it by an arrangement under which the corporation tax would be reduced from its present rate of fifty per cent to twenty-five per cent and the savings to the corporation (twenty-five per cent) would be distributed to shareholders and company employees on an equal basis. ${ }^{48}$ Obviously, such a bill may very well find strong support among management, shareholders, and wage earners alike, although the French Treasury is unlikely to be particularly enthusiastic about it, given the fact that the latter stands to lose some I.7 billion dollars annually if it becomes law.

It should be noted that the repercussions which followed the publication of the French Prime Minister's tax returns have not been confined to France. West Germany has felt it advisable to examine its own decision to adopt the imputation system and it now seems quite clear that, regardless of the outcome of this reappraisal, the proposed tax reforms will not be adopted by January $I$, I974, as previously thought. ${ }^{49}$

Even more confusing in the context of these supposed trends towards corporate tax harmonization is the issuance of the van den Tempel Report in I970 on corporation tax and individual income tax in the EEC which was made at the request of the Commission of the European Communities. After an intensive analysis of the three alternatives available, this study concludes that, viewing the domestic and international aspects of the various systems together, the classic system is the most

\footnotetext{
${ }^{47}$ This history is noted in the study undertaken by Professor A. J. van den Tempel at the request of the Commission of the European Communities. See Commassion of THE Edropean Communties, Corporation Tax and Individual Income Tax, Competrtion: Approximation of Legislation Series No. 15 , at 7 (1970) [hereinafter cited as the VAN DEN TEMPEI RePORT].

${ }^{48} \mathrm{CCH}$ Comar. Mrt. Reports: Euromarket News, Mar. 2I, I972, at I-2.

${ }^{\circ} I d$.
} 
suitable for the European Community. ${ }^{50}$ The report has not yet been formally adopted by the Commission, though it is understood that the latter is strongly in favor of it. ${ }^{51}$

From this encapsulated history of corporate tax development in Europe, it would appear that the statement of the Select Committee, which has, in fact, been accepted by the Chancellor of the Exchequer, that the adoption of the French type of imputation system would contribute to the harmonization of corporate taxation in the Community is, at best, optimistic and, at worst, incorrect. ${ }^{62}$ Be that as it may, we have now on record the Chancellor's proposal to introduce such a system in the United Kingdom in 1973, and it is this system which an investor will have to take into account in structuring his existing or future investments in the U.K.

\section{B. Imputation and the Overseas Investor}

Although it is quite clear that the imputation system introduces many technical complications into the tax laws, creating an extra burden on both tax administrator and taxpayer, it is with the international aspects of the tax that the overseas investor will be most concerned at this time. And here he is clearly placed at a distinct disadvantage. According to the Finance Bill now before the U.K. Parliament, profits of a company resident in the United Kingdom will be subject to corporation tax of, say, fifty per cent, whether or not distributed. If, however, dividends are subsequently paid from these profits to domestic shareholders, the company will be required to make an advance payment of its corporate tax equal to three-sevenths of the dividend paid to the shareholders. The latter will then be entitled to a tax credit of the same amount against their own income tax liability for the dividends which they receive. ${ }^{53}$

If this system were completely non-discriminatory, foreign shareholders would, of course, be entitled to claim the same credit. However, foreign shareholders, who do not pay British income tax, are not able to benefit from the system unless a cash refund is actually made to them. Without such a refund the position of the foreign shareholder in a domestic concern is inferior to that of the local shareholder owning shares in the same company. As the Select Committee of the House of Commons

\footnotetext{
${ }^{50}$ VAN DEN TEMPEL REPORT $4 \mathrm{r}$.

${ }^{51}$ See Structure de l'impót des sociétés-Allégement de lá imposition économique des dividends, $4 \mathrm{I}$

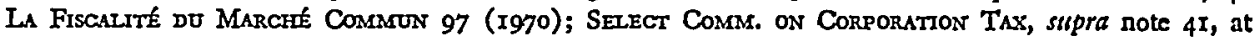
128, para. 485 .

${ }_{52}$ However, it should be stated that the Select Committee appeared to recognize that the adoption of the imputation system may well be no more than an interim step towards harmonization along the lines recommended by Professor van den Tempel, Sexect Coma. on Corporstion TAx, supra note 4I, at 128, though its reference to a "spontaneous harmonization" occurring within the Six, id. at 13r, para. 506, does not appear to be supported by the evidence.

58 Finance Bill (Bill III) I972, cl. 79(2). The actual rate of corporation tax for 1973 will be fixed by the Finance Act 1974 as is normal. However, in the White Paper published with the Finance Bill 1972, the Government has used a rate of $50 \%$ to illustrate how the system will work. U.K. Government White Paper, published by order of the Chancellor of the Exchequer as Reform of Corporation TAx, CMND. No. 4955 , at 3 (1972).
} 
pointed out, it is precisely this discriminatory feature which provides one of the stronger incentives for preferring this system of corporate taxation in Britain over the two rate arrangement. Its existence automatically places the United Kingdom in a stronger position from which to negotiate or renegotiate double taxation agreements with other jurisdictions.

In order to eliminate some of the discriminatory aspects of the system as regards nonresident shareholders, the Finance Bill has reserved power to the Government to extend the tax credit to those countries with which the United Kingdom presently has double taxation agreements. ${ }^{54}$ However, while it seems reasonably clear that such credit will be made available to individual shareholders resident in these countries, there is no indication as to how the United Kingdom intends to deal with dividends paid to foreign, parent corporations in these jurisdictions. ${ }^{55}$ The difficulty which could arise in this respect is well illustrated by the attitude of the authorities in France, who have made it abundantly clear that the French tax credit will not be extended to cover those situations in which the shares of a French company are held by a foreign corporation. If, for example, a U.S. company holds more than a ten per cent interest in a French concern, it will not be entitled to any credit on dividends which it receives from the latter, even though it may be able to show that such dividends are passed on to its own individual shareholders in the U.S. ${ }^{56}$

If Britain adopts the same approach, the problems for the American corporate investor may be considerable. As and when distributed as dividends, profits from British based enterprises may have to bear an aggregate British tax in excess of the U.S. rate. ${ }^{57}$ This, of course, would create surplus foreign tax credits for the United States parent company, the usefulness of which would depend on the existence of other overseas income bearing tax at a rate lower than the existing federal tax rate. ${ }^{58}$

In case it be thought that the imputation systems as proposed in the United Kingdom is being designed especially to discriminate against foreign companies which

\footnotetext{
Et Finance Bill (Bill IIr) I972, d. 93(2).

ES However, it should be noted that the Finance Bill speaks of conferring the right to the tax credit on "persons not resident" in the U.K. and not just on non-resident individuals. Id.

${ }^{68}$ See Convention with France with respect to Taxes on Income and Property, July 28, 1967, art. 9, [1968] 4 U.S.T. 5280, T.I.A.S. No. 6518, as amended by supplementary protocol of Oct. 12, 1970, art. I, T.I.A.S. No. 7270 .

${ }^{67}$ Assuming the rate of corporation tax in Britain is fixed at $50 \%$ under the new system, as used in the examples in the White Paper, REForm of Corporation TAx, supra note 53, and the dividend withholding tax to the U.S. is $15 \%$, as under the present U.S.-U.K. Double Taxation Agreement, the aggregate burden would amount to $57 \frac{1 / 2}{2}$. The present Double Taxation Agreement is contained in Convention with Great Britain and Northern Ireland for the Avoidance of Double Taxation and the Prevention of Fiscal Evasion with Respect to Taxes on Income, Apr. 16, 1945, 60 Stat. I377, T.I.A.S. No. 1546; as modified by the supplementary protocols of June 6, 1946, 60 Stat. 1389, T.I.A.S. No. 3165; May 25, 1954, [1955] I U.S.T. 37, T.I.A.S. No. 3165; Aug. 19, 1957, [1958.] U.S.T. I329, T.I.A.S. No. 4124, Mar. 17, 1966, [1966] I U.S.T. 1254, T.I.A.S. No. 6089. However, as the Finance Bill 1972 is now drawn, it appears that there will be no withholding tax payable under the new system when dividends are distributed to a non-resident corporate sharcholder. Finance Bill (Bill III) r972, cl. 82(5)(a); Finance Act I97I, ch. 68, $\$ 32(1)$.

ES Assuming, of course, the U.S. corporation elected the overall limitation under INT. REv. CODE or I954, $\$ 904(\mathrm{a})(2)$.
} 
have or are considering corporate investment in Britain, it should be made clear that British multi-national companies which derive most of their own income from investments outside the United Kingdom also have grounds for complaint under this new scheme. As the advance corporation tax in respect of any distribution may only be set off against the company's liability on income charged with corporation tax, dividends paid from foreign source income which has borne no United Kingdom tax because of double taxation relief will, in effect, suffer the economic double taxation in the hands of the shareholders which the imputation system is supposed to avert. ${ }^{\text {.0 }}$ If, for example an English company earned all of its profits abroad and paid foreign tax at fifty per cent on such income and if the individual shareholders were paying personal tax at a marginal rate of forty per cent, the net value of the dividend paid to the shareholders would be thirty per cent of the company's profits because no setoff would be available to the distributing corporation under the proposed rules. If, on the other hand, the U.K. company earned all of its profits domestically and paid only U.K. corporation tax at, suppose, fifty per cent, then the net value of the dividend to the recipient would be forty-five per cent of the total profits, since the full set-off would be available. ${ }^{60}$

The Government Greer Paper on the Reform of Corporation Tax made it quite clear that in no case will the United Kingdom tax in respect of corporate distributions be allowed to fall below a set minimum. For example, if the potential rate of corporation' tax on distributed profits were less than thirty per cent because of foreign tax credits allowed in respect of the company's income, the payment of the three-sevenths of the dividend to the Inland Revenue, as required under the Finance Bill, $^{61}$ would mean; that the company would, in effect, be paying a supplementary charge comparable to the précompte mobilier imposed in France on dividends paid out of profits which have not borne French tax. ${ }^{62}$ By requesting the U.K. company to pay over such an amount in respect of each distribution, the British Exchequer will avoid having to credit or repay to shareholders tax which it never received. In essence, therefore, the company will continue to act as it does at the present time; that is, as a collecting agency for the advance payment of income tax by shareholders on dividends paid to them. This, of course, is different from the normal case in which tax is withheld on dividends paid out of profits which have borne full United Kingdom taxation. There the withholding is regarded as

\footnotetext{
${ }^{59}$ Finance Bill (Bill III) I972, cl. 80(I). However, in this situation, the Bill does permit the company to carry back the advance corporation tax and set it off against corporation tax paid in the two years prior to the accounting period in question, or to carry it forward one year for set-off purposes. Id. cl. $8 \mathrm{o}(3,4)$.

${ }^{0}$ This discrepancy was recognized by the Chancellor of the Exchequer, supra note $\mathrm{x}$, at 1358-60. As a concession, therefore, the Finance Bill (Bill $\mathrm{xII}$ ) I972, cl. 94, extends the "overspill relicf" at its 1971-72 level until 1976-77. This relief was introduced in 1965 to compensate companies trading overseas for loss in foreign tax credits brought about by the reduction in U.K. taxes against which credit for foreign taxes could be taken. Sce Finance Act 1965 , ch. 25, $\$ 84$.

${ }^{81}$ Silpra note 53 .

${ }^{62}$ See Statute No. 65-566 of July 12, 1965, [1965] E.E.C. J.O., July I3, at 6003, [1965] D.S.L. 228; Decree No. 67-774 of Sept. II, x967, art. 3, [1967] E.E.C. J.O., Sept. 16, at 9237, [1967] D.S.L. 337.
} 
an advance payment of corporation tax and not as income tax paid on behalf of the shareholders. ${ }^{63}$

\section{Harmonization of Corporation Tax}

Although it is unlikely that corporation taxes will be harmonized in Europe in the very near future, some attempts have been made to approximate the laws of the member states in certain specific areas. Thus, in 1969 , drafts of two directives were submitted to the Council of Ministers which were designed to create a common tax system throughout the EEC to deal with reorganizations between companies and with the assessment of a parent company having subsidiaries in different member countries. ${ }^{6}$ Neither draft has been adopted as yet by the Council, and it is thought unlikely that they will be in their present form. ${ }^{65}$

The two proposals of the Commission are indications of the complexity of the problem confronting the Community in harmonizing the corporation tax laws of the member states. More than ten years ago the Commission set up a working party to study the basic provisions for computing income and similar taxes levied on enterprises by the member states, particularly in respect of such matters as depreciation, investment incentives, valuation of inventories, and treatment of capital gains and losses. In the report which was subsequently issued, the working party noted the widespread differences which existed in the local laws dealing with these matters and emphasized that all of these differences had some bearing upon the ultimate goal of full economic integration of the Common Market. Not surprisingly, however, the report offered very few recommendations as to how these disparities could be removed. ${ }^{68}$

Although the drive to establish a European company will assist in the harmonization of the tax laws, it is felt that this particular concept is not vital to such harmonization. The creation of a European company will not in and of itself provide solutions to the very fundamental problems involved in rationalizing the

\footnotetext{
${ }^{63}$ Reform of CoRporation TAX, supra note 42 , at 12 . However, it is clear that the taxes withheld by the U.K. company, even in the précompte mobilier situation, will not be regarded by the U.K. as dividend withholding taxes for purposes of the present U.S.-U.K. Double Taxation Agreement.

' Proposed Council Directive on the Common Tax System for Mergers, Split-ups, and Transfers of Assets Involving Companies of Different Member States, in I CCHI CoMm. MKT. REP. I33I4. E.E.C. J.O. March 22, I96r, at $\mathrm{C}_{39} / \mathrm{x}$. Proposed Council Directive on the Common Tax System for Parent Companies and Subsidiaries of Different Member States, in I CCH CoMM. Mxt. REP. I 33 r6 E.E.C. J.O. March 22, 1969 , at $\mathrm{C}_{39} / 7$. It is interesting to note that both these directives recommend a common tax system to deal with tax problems arising from these particular situations and not just a harmonized one.

${ }^{05}$ Indeed, both Germany and Holland have voiced objections to the directives as originally proposed. See Christiaanse, Tax Harmonization in the European Common Market, 24 The TAx Executrve, Oct., I97I, at Io, II.

${ }^{10}$ For a description of the terms of reference of this Working Group, see 2 European TAXation I66-68 (1962) and for a brief summary of working party's report, see I CCH CoMM. MKT. REP. I33II (xg65, I97I). These disparities will assume greater significance as the member states move closer to full economic and monetary integration. See "Mesures d'aménagement en matière d'impôts directs en vue de faciliter le developpement et l'interpénétration des marches de capitaux dans la C.E.E." E.E.C. DOC. COM (69) 201, Bruxelles, Mar. 5, 1969.
} 
diversity of tax laws which presently exists in the EEC and which, as the Neumark Report rightly points out, reflects, in many instances, deeply engrained social and political values. ${ }^{67}$

While there is good authority for believing it unlikely that France or Germany will ever be prepared to abolish a system which militates against economic double taxation of corporate profits, ${ }^{68}$ recent developments have thrown some doubt upon the accuracy of this conclusion. ${ }^{69}$ Moreover, if the real aim of any tax law is the reduction of the overall burden on corporate profits, as and when received by the shareholders, then there is much to be said for retaining the classic system while reducing the rate of corporation tax. ${ }^{70}$ This would, in itself, eliminate many of the complications, technical and otherwise, which are involved in applying the imputation and the two rate system and, at the same time, would secure a neutrality of tax burden in the international field which Professor van den Tempel and others believe to be an essential prerequisite for any harmonized system in the Common Market. ${ }^{71}$

\section{III}

\section{Industrial and Regional DeVElopMent}

Apart from the explicit changes in the tax laws of the United Kingdom which have been announced, the Chancellor of the Exchequer's Budget statement of 1972 also proposed substantial amendments to the system of investment incentives available in the United Kingdom. These new incentives, effective March 22, 1972, provide an extremely attractive inducement for overseas business contemplating investment in the U.K. ${ }^{72}$ Indeed, it is this very attractiveness which may create difficulties for Britain as and when it becomes a full member of the Community. ${ }^{73}$

The incentives announced by the Chancellor of the Exchequer fall into two categories: the first consists of improved tax allowances and depreciation rates for

\footnotetext{
${ }^{67}$ NetUMark REPORT 102.

${ }^{68}$ See, e.g., Christiaanse, supre note 65 , at 21 .

${ }^{60}$ See text accompanying notes 49 \& 50 stpra.

${ }^{70} \mathrm{Cf}$. Kaldor, The Economic Effects of Alternative Systems of Corporation Tax, in Senect Comm. on Corporation Tax, supra note 45 , at 248 .

${ }^{71}$ VAN DEN TEASPE REPORT 37. Abnormal losses of revenue resulting from dividends paid to nonresidents could be avoided by adjusting the rate of withholding tax. See also European Economic Community Commisston, The Development of a European Capital Market 3it-12 (ig66) (Prof. Claudio Segré, Chairman). The reasons for introducing the imputation system to replace the classic arrangement are not particularly convincing in the first place. Although both France and Germany contend that the former is more conducive to the creation of a large, smooth-working capital market, this argument scarcely bears close examination, given the fact that the two largest capital markets in the post-war world have experienced their period of greatest development under a classic system of corporation tax. A possible and more persuasive explanation is that the move towards the new structure is the result of pressure from institutional investors which obviously have a great deal to gain from the change. However, there is very little evidence at this time to support this hypothesis. See Ministerialrat Wrede, Reform of the Corporation and Trade Tax, June 23, I971, explaining the reasons for the proposed tax reforms in West Germany. An unofficial translation is included in Sezect CoMm. on Corporation TAX, stlpra note 45, at 203-I0.

${ }^{73}$ Secretary of State for Trade and Industry, Industrual and Regional Development, CMnd. No. 4942, para. 24 (I972) [hereinafter cited as Industrial snd Regional DevelopMent].

${ }^{73}$ See text accompanying notes 80 \& $8 \mathrm{I}$ infra.
} 
investment in plant, machin'ery, and buildings on a country-wide basis, and the second provides for cash grants for investment in certain depressed areas in the United Kingdom. These cash grants will go towards capital expenditure on new plant, machinery, an'd buildings in the development and special development areas. However, in the so-called intermediate areas and, for a short time, in derelict land-clearance areas, they will be confined to capital expenditure on buildings only. ${ }^{74}$

An interesting point to note as regards the tax incentives is that they will be given on the full capital expenditure incurred in acquiring new plant, machinery, and so on, notwithstanding that part of the expenditure may be financed by regional development grants. This contrasts sharply with the legislation in effect prior to March 22, I972. Under the earlier law, sixty per cent (eighty per cent after July 20, r97I) of the expenditure for new or used machinery and plant facilities could be written off as depreciation for tax purposes in the first year. The remaining part of the outlay could then be depreciated at a rate of twenty-five per cent on a declining balance. ${ }^{75}$ However, depreciation was based upon the actual expenditure incurred by the taxpayer: if any subsidies or grants were received from the Government, then the basis for depreciation was reduced by a corresponding amount.

The new proposals envisage several changes. Free depreciation in the form of a I0o per cent first year allowance will be permitted throughout the country on all investment in plant and machinery (other than passenger cars). This depreciation will apply equally to n'ew and used equipment, regardless of whether the investment takes place in a development area or not. At the same time there will be extended to all companies the right, previously confined to companies in development areas, to carry back trading losses attributable to free depreciation and to set them off against profits for the three preceding years. ${ }^{76}$ In addition', new industrial buildings and structures will receive an initial allowance in the first year of forty per cent, so that the level of tax allowances will be the same for all qualifying buildings, both inside and outside the assisted areas. ${ }^{77}$

Regional development cash grants will be made available for up to twenty-two per cent of the cost of new plant, machinery, and buildings established in or used in special development areas. ${ }^{78} \mathrm{Up}$ to twenty per cent cash grants will be available

\footnotetext{
7t These various areas are defined in INDustrial and Regronar Development, supra note 72, at I2, 13.

${ }^{75}$ In the development areas as defined under the Local Employment Act, 8 \& 9 Eliz. 2, ch. I8, § I (1960), expenditure on new machinery and plans could qualify for "free depreciation"- that is, a write off of $100 \%$ in the first year if the taxpayer so elected. Finance Act $197 x$, ch. 68, $\$ \$ 4 x(3), 42(2)$.

${ }^{70}$ Industrial aNd Regional Development, supra note 72, para. xI(a). See Finance Bill (Bill rir) I972, cl. $65(2)(b)$. The term "free depreciation" is a little misleading in that, save in the case of new ships, it really amounts to an increase in the amount which can be written off in the first year. If the total expenditure is not deducted in the first year, the remainder can only be written off at the rate of $25 \%$ on a declining balance. Finance Bill (Bill III) r972, cl. 65(2) amending Finance Act I97I, ch. $38, \S 42$.

${ }_{77}$ Finance Bill (Bill IIr) $1972, \mathrm{cl} .65(2)(\mathrm{c})$.

${ }^{78}$ Indostratal and Regional DeVelopment, supra note 72, para. I6.
} 
for new equipment and buildings in ordinary development areas and for buildings in the intermediate and derelict land clearance areas. ${ }^{79}$

Clearly, the incentives are quite generous, and with the extension of the areas in the U.K. which are eligible to receive them, they provide a most attractive inducement for investment in the United Kingdom. However, notwithstanding the fact that there is apparently no time limitation on incentives other than those pe1. taining to the derelict land clearance areas, it is possible that when England becomes a full member of the Common Market, these incentives may have to be adjusted to meet the requirements established by the EEC. The Community has made it quite clear that, as a matter of principle, competition within the EEC should not be affected by direct measures of the member states such as aids. In order to eliminate any distortion of this kind, the domestic laws and the measures of each country are required to conform to the criteria laid down in Article 92 of the Rome Treaty. This particular provision recognizes that regional aids given by individual member states cannot be abandoned entirely, and certain types of assistance are thus accepted automatically as being compatible with the Common Market. ${ }^{80}$ Other forms of help which do not fall within these prescribed categories, however, are subject to approval by the Commission which has been given very broad powers under Article 93 to examine all systems of aid adopted by the member countries and to order such changes to be made to them as may be necessary to ensure compatibility with the aims of the EEC.

Although it is doubtful that Britain's overall regional aid program will be proscribed by the Commission, it is possible that certain aspects of it may have to be altered to comply with criteria established under Article 92. The tax incentives which have now been made available to all parts of the U.K. may be particularly vulnerable in this regard. ${ }^{81}$

\section{CoNCLUSION}

This paper has attempted to deal with just a few of the many implications in the field of taxation of Britain's joining the Common Market. Some of these implications have already manifested themselves in the tax reforms proposed by the present Government in the United Kingdom, especially as they relate to the introduction of the VAT in 1973 and the move to the credit or imputation system of corporate taxation.

At this stage, there is little point in going into the merits or demerits of a value added tax for Great Britain: its advent is a foregone conclusion, whether the country

\footnotetext{
${ }^{70}$ Id. These grants will only be available for two years in derelict land clearance areas. Id. at Ir.

${ }^{80}$ See Rome Treaty, art. 92(2). As long as these aids relate to areas of unemployment, they will satisfy the requirements of the Common Market.

${ }^{81}$ See the Commission's recent instructions to Belgium to reform its state aid system, E.E.C. J.O., May 4, 1972, at Lro5/x3. The main reason for the reform was that the aid was virtually nationwide, applying to $4 \mathrm{I}$ of the country's 43 districts. A general study of the interaction of the regional policies of Britain and the Common Market is contained in H. LiNd, Regional. Policy IN BRITAIN AND THE SIX (1970).
} 
goes in or stays out of the Common Market. The fact that the tax was rejected

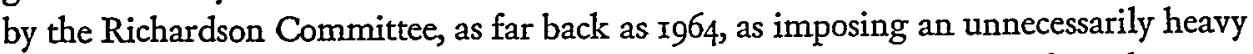
burden upon the administrative authorities and providing no particular advantage over the existing purchase $\operatorname{tax}^{82}$ will not prevent its adoptiont in the U.K.; and logically of course, it could not, given the present Government's commitment to the Common Market. ${ }^{83}$ It seems even more fruitless to examine the tax from the point of view of its possible economic advantages or disadvantages. Although experience in other countries shows that a rise in the cost of living is likely to follow the introduction of the VAT, ${ }^{84}$ this view is by no means accepted by all the experts. ${ }^{85}$ And there is, of course, a complete divergence of opinion as to its regressive nature and its impact on the economy as a whole. ${ }^{86}$

For the United Kingdom, there is now no alternative but to accept and live with the VAT. However, it is obvious that the majority of the taxpaying public in Britain is ill-equipped at the present time to cope with the inception of this new levy. Although the authorities themselves have given a great deal of study to the impact of the tax and are, no doubt, prepared in large measure to adapt existing, or create new, machinery to collect the tax, there is no indication that the taxpayers themselves are anywhere near as ready to deal with the problems with which they will be faced in' $1973 .^{87}$ In this area, at least, some confusion is inevitable.

Further confusion can also be expected as and when the technical inadequacies of the legislation become apparent and conceptual anomalies are exposed. However, while these may have some effect upon the foreign trader dealing with the United Kingdom, there is no reason to think that such obstacles will pose insuperable problems.

A far greater source of difficulty will be the need to adjust the United Kingdom's

\footnotetext{
${ }^{83}$ Commitee op Turnover Taxes, Report, CMnd. No. 2300, paras. 124, 323 (I964) (Sir Gordon Richardson, Chairman).

${ }^{83} \mathrm{It}$ is interesting to note that the National Economic Development Office approved the introduction of a VAT, provided it was accompanied by a significant off-setting reduction in direct corporate taxation. See National Econ. Development Office, Value Added Tax 7 (2d ed.). The corporation tax reforms proposed by the present U.K. government do not appear to satisfy this latter condition.

84 See Aims of Industry, Argunent: Reflections on Value Added Tax (Ilersic) and Too Early for VALUE ADded TAX (Thorne), Thorne at I8 (I972), which summarizes the effects on prices of the introduction of a VAT in certain countries in Europe.

${ }^{85}$ See, e.g., AIms of Indostry, supra note 84 , Ilersic at Io. Schone, Foreward, in ThE VAlue-ADded Tax, viii (T. Rybcynski ed. I969). The National Institute of Economic and Social Research has calculated the introduction of VAT at a rate of $10 \%$ might raise prices by nearly $21 / 2 \%$ if there are no compensating cuts in excise duties. Even with such cuts, the rise in overall prices is likely to be equal to $1 \%$. See Nat'l Institute Econ. Rev., May, 1972, at 21.

${ }^{80}$ See, for example, the wide range of differing views expressed in the preliminary analysis of the Value Added Tax by the group which has chosen the name Taxation with Representation (public interest tax lobby, 2369 N. Taylor St., Arlington, Va.). See also Stout, Economic Aspects of a Value Added Tax in the U.K. in The VALUE-ADDed TAX I (T. Rybcynski ed. 1969).

87 This, of course, is one reason why some writers are advocating a delay in the introduction of the VAT in the United Kingdom similar to that requested and obtained by certain member states in the Common Market. See, e.g., Thorne, supra note 84 , at 24 . However, all businesses are to receive a general guide to VAT late in the summer of 1972. See The Economist, Apr. 8, I972, at 62.
} 
legislation to meet the requirements of harmonization in the EEC. As previously noted, ${ }^{88}$ the European Commission has already indicated that by 1973 it intends to introduce a proposal for harmonization' of the VAT base, and this in itself could result in far reaching changes in the British law. The Commission's avowed intention to develop a uniform definition of the tax base, to define taxable and exempt activities, to establish methods for determining the base, and to create special measures to deal with particular sections of the Community's economy ${ }^{80}$ may well require a complete change of emphasis in the VAT legislation of the United Kingdom.

The changes in the corporation tax system will, of course, have an even greater impact on investment in Great Britain. Mention has already been made of the fact that the imputation or credit system of corporation tax, as presently conceived, will discriminate against the overseas company establishing a branch or a subsidiary in the United Kingdom, ${ }^{90}$ though just how far this will affect a United States corporation will depen'd in part on how the Double Taxation Agreement between the United Kingdom and the United States is renegotiated. Despite the fact that the United Kingdom has preferred the imputation system because of the increased strength which it will give the British bargaining position in such negotiations, ${ }^{\text {pd }}$ there is no reason to believe that the Internal Revenue Service and members of the United States Treasury are not fully able to take care of themselves in future discussions concerning the agreement. Indeed, an examination of the renegotiated convention which resulted from the $\mathrm{r} 965$ changes in the British tax law bears eloquent testimony to their competence. ${ }^{92}$ However, until such time as the Double Taxation Agreement is renegotiated, following the proposed changes in the United Kingdom corporation tax, there is bound to be a period of uncertainty, with all the attendant problems attached to it.

As regards the overall benefits which may be derived from these various proposals, these will obviously depend to a considerable extent upon the developments which occur after Britain's accession to the Common Market. In this particular respect it is as well to recognize that, from a general economic point of view, the United Kingdom's joining the EEC is essentially an act of faith. ${ }^{93}$ Even the most

\footnotetext{
${ }^{88}$ See text accompanying notes $33 \& 34$ supra.

${ }^{89}$ Supra note 33 .

s0 See text accompanying note 57 supra.

o1 See text accompanying note 45 supra.

${ }^{2}$ See, for example, the wording of Article I5 (4) of the Supplementary Protocol of Mar. 77 , I966, to the U.S.-U.K. Double Taxation Agreement, supra note 57, designed to deal with problems created by reallocations of income under Section 482 of the Internal Revenue Code, 1954 , at the expense of thic U.K. Exchequer. A comparison of the language of this section with Article 15(3) of the Protocol is instructive as regards the negotiating capabilities of the U.S. Treasury.

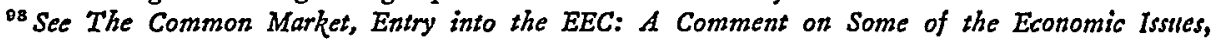
-NAT'L InstrTUte Econ. Rev., Aug., I97r, at 35-36. In the writer's opinion, this is the best and most objective summary of the static and dynamic economic results which may ensue from the U.K.'s entry -into the EEC. It should be noted that one of the more important conclusions reached in this study is ithat the medium and long term advantages (the so-called "dynamic benefits") cannot be estimated with any degree of precision and, in any case, depend upon certain satisfactory policy adjustments in the UU.K. and the acceptance of certain political assumptions. Id. at 57-58.
} 
ardent pro-Market advocate will not deny that, in the short term, there will be considerable expense involved in the United Kingdom's entry and a severe strain put upon its balan'ce of payments by the possible outflow of investment from Britain into the Common Market. ${ }^{94}$ However, assuming that the minimum growth rate of one half of one per cent a year is achieved, the country would in five years have an annual increase in resources in excess of one billion pounds. ${ }^{95}$ Thus, for those prepared to commit themselves to this act of faith, the advantages, medium and long term, which could ensue from the proposals may be considerable. For the more skeptical, however, the suggested changes will probably be regarded as heralding a false dawn rather than the start of a new day.

\footnotetext{
24 See, e.g., The Economist, Britain Into Europe, 9-10, I5-I7 (197I) (reprints of articles appearing in The Economist, Apr. 24-July Io, I97x.)

${ }^{05}$ Id. at 9.
} 